\title{
Gene expression profile of human thyroid cancer in relation to its mutational status
}

\author{
Dagmara Rusinek, Sylwia Szpak-Ulczok and Barbara Jarzab \\ Department of Nuclear Medicine and Endocrine Oncology, Maria Sklodowska-Curie Memorial Cancer Center and Institute of Oncology, Gliwice Branch, \\ Wybrzeze Armii Krajowej 15, 44-101 Gliwice, Poland \\ (Correspondence should be addressed to B Jarzab; Email: bjarzab@io.gliwice.pl)
}

\begin{abstract}
This review describes the gene expression profile changes associated with the presence of different mutations that contribute to thyroid cell carcinogenesis. The results are discussed in the context of thyroid cancer biology and of the implications for disease prognosis, while the diagnostic aspect has been omitted. For papillary thyroid cancer (PTC), the most characteristic gene expression profile is associated with the presence of BRAF mutation. BRAF-associated PTC differ profoundly from RET/PTC or RAS-associated cancers. Simultaneously, they retain many characteristic gene expression features common for all PTCs, induced by the alternative mutations activating MAPK pathway. Although the difference between papillary and follicular thyroid cancer (FTC) is significant at the gene expression profile level, surprisingly, the RAS-related signature of FTC is not well specified. PAX8/peroxisome proliferator-activated receptor $\gamma$ $(P P A R \gamma)$ rearrangements, which occur in FTC as an alternative to the RAS mutation, are associated with specific changes in gene expression. Furthermore, the difference between well-differentiated thyroid cancers and poorly differentiated and anaplastic thyroid cancers is mainly a reflection of tumor degree of differentiation and may not be attributed to the presence of characteristic mutations.
\end{abstract}

Journal of Molecular Endocrinology (2011) 47, R91-R103

\section{Introduction}

Gene expression profiling of thyroid tumors has expanded our knowledge of the molecular biology of thyroid cancer. Several recent reviews addressed the biological and diagnostic aspects of microarray-based studies of thyroid cancer (Eszlinger et al. 2007, Handkiewicz-Junak et al. 2010, Kouniavsky \& Zeiger 2010). However, this field remains open and new reports continue to appear, thus, updating its present status is necessary. The aim of this review is to describe the gene expression profile changes associated with different mutations that contribute to thyroid carcinogenesis (see Kondo et al. (2006) for an overview of genetic alterations involved in the development of thyroid cancer). The results will be discussed in the context of thyroid cancer biology and of the implications for disease prognosis, while the diagnostic aspect will be omitted. Only follicular cell-derived neoplasms will be considered and emphasis will be placed on papillary thyroid cancer (PTC), the most frequent histotype, since it has been the subject of the majority of microarray-based studies published to date.

\section{Transcriptome of papillary thyroid cancer}

Papillary thyroid cancer develops directly from the thyroid cells and does not have a benign intermediate. The majority of PTCs exhibit the BRAF V600E activating point mutation, which is observed in $40-70 \%$ of cases, and is more frequently found in older patients with more aggressive disease (see Handkiewicz-Junak et al. (2010) for review). Chromosomal rearrangements involving receptor tyrosine kinase genes such as RET/PTC or $T R K$ rearrangements, or rarely, activating $R A S$ point mutations, are other molecular events involved in the activation of the MAPK-ERK cascade (mitogen activated protein kinases cascade) and in the development of PTC (Kimura et al. 2003, Fagin 2005).

\section{The BRAF V600E mutation and the gene expression profile of papillary thyroid cancer}

$B R A F$ mutation is associated with the morphological and functional alterations characteristic of the PTC phenotype. The detection of BRAF mutation is a specific but not sensitive feature of papillary thyroid

DOI: 10.1530/JME-11-0023 Online version via http://www.endocrinology-journals.org 
cancer, since this mutation has not been observed in benign thyroid lesions (Eszlinger \& Paschke 2010, Soares \& Sobrinho-Simoes 2011). The most distinct phenotypic feature of BRAF-positive tumors is the presence of papillary structures that determine the diagnosis of the classical variant of PTCs (Nakamura et al. 2005, Xing et al. 2005, Frasca et al. 2008). Notwithstanding, this may be a secondary phenomenon. Jakubowski \& Hunt (2009) compared the frequency of $B R A F$ mutation in PTC showing a mixed papillary and follicular growth pattern and observed no difference, the $B R A F$ mutation status was always concordant, in both areas showing papillary and follicular growth type, at the overall rather high $B R A F$ mutation frequency.

Functionally, the presence of the BRAF oncoprotein results in the inhibition of membrane sodium-iodide symporter (NIS) expression. This is the most often evoked explanation for the clinically well-known tendency of BRAF-positive PTCs to be non-radioiodine avid, to have a more aggressive clinical course, and to have a poorer prognosis (Xing et al. 2005, Handkiewicz-Junak et al. 2010). However, a deeper insight into the molecular profile of PTC and the presence of different mutations reveals a more complex network of molecular interactions that should be further elucidated both on the basis of gene expression research and on the basis of prospective clinical studies. This controversy cannot be clarified without integrating PTC variants with tumor invasiveness (Soares \& Sobrinho-Simoes 2011). In addition, without neglecting the role of the BRAF mutation in PTCs with poor prognosis, there are many other genetic alterations known to be associated with the progression of papillary thyroid cancer to more aggressive phenotypes, including mutations of TP53 (Fagin et al. 1993, La Perle et al. 2000), under-expression of E-cadherin, or dysregulation of catenin signaling (Karim et al. 2004).

The first study devoted to the comparison between PTC with BRAF mutations or RET and TRK rearrangements was published by Frattini et al. (2004), who stressed similarities in the gene expression profiles of PTC with various mutations. These authors were the first to detect a difference in the gene expression between BRAF-positive PTCs and those with receptor tyrosine kinase-related rearrangements (Frattini et al. 2004). Giordano et al. (2005) showed that the gene expression profile of the BRAF-associated PTC differs profoundly from the RET/PTC or RAS-associated PTC. Using a significance criterion of $P<0 \cdot 01$, these authors found over 3800 genes differentially expressed in PTC with $B R A F$ compared to those with $R E T$ alterations. They also indicated that tumor mutational status was more strongly correlated with gene expression profile than its morphology. In opposition to Frattini et al. and Giordano et al. hypothesized that these mutations signaled through alternative pathways and might be related to tumors with discrete mutation-specific phenotypic and biological features. One of the groups of genes most distinctly over-expressed in BRAFmutated PTCs was related to the regulation of the immune response (TM7SF4, CLECSF2, STAT1, and $L Y 75)$. The proposed unique role of the BRAF mutation in initiating a specific immune response in PTC was supported by further SAGE data (Oler et al. 2008). Comparing the BRAF status in a set of metastatic and non-metastatic PTCs with their gene expression profiles, Oler et al. found that cystatin 6 (CST6) and the chemokine gene CXCL14 were over-expressed and positively correlated with the BRAF V600E mutation, which was in agreement with the data of Giordano $e t$ al. Both CST6 and CXCL14 are putative downstream genes in the BRAF/MEK/ERK signaling pathway, CXCL14 being involved in the homeostasis of macrophages. Furthermore, the in vitro studies of Mesa et al. (2006), who focused on the early molecular consequences of different mutations leading to PTC, showed that $B R A F-$ induced genes included many involved in the immune response, mostly in the innate response, such as the chemokine (C-C motif) ligands 2, 7, 15, and granulocyte-macrophage colony-stimulating factor 2 ( $M C P 1$, $M C P 3, C C L 15$, and GM-CSF respectively). In this study, a preferential induction of $M M P 3$ and $M M P 9$ and the exclusive activation of $M M P 13$ were observed in PCCL3 cells with the BRAF mutation compared to a cell line with RET/PTC rearrangement. The authors related these differences to ERK activation, which was much higher because of the BRAF mutation. The association of MMPs (matrix metalloproteinases), which are able to degrade all components of the extracellular matrix, with the invasive phenotype and poor prognosis is well known in PTC (Klopfleisch et al. 2011, Yang et al. 2010, Horndler et al. 2011). The activation of BRAF in PCCL3 cells downregulated the mitochondrial respiratory chain (MRC) complex 1 genes. There are contradictory data in the literature concerning the influence of the inhibited MRC complex 1 genes on cell survival, but the most predominant studies indicate that it protects the cells from apoptosis (Mesa et al. 2006).

Although Giordano et al. (2005) identified many BRAFrelated genes showing differential expression between RET/PTC-positive or RAS-positive PTCs, these authors did not analyze other factors that could differ in the population of BRAF-positive and BRAF-negative tumors that could cause gene profile differences (e.g. age, disease stage, or other still unknown mutations that BRAF may co-segregate with). In addition, an independent validation of the BRAF-related gene list was not performed. The multifactorial nature of gene expression changes in malignant tumors, which is well known from the studies of other cancers (Rhodes et al. 2004), underscores the need for multivariate analysis of the association between gene expression profile and different mutations. In univariate 
approaches, the risk of incorrectly attributing an observed change in gene expression to the presence of the $B R A F$ mutation is high. Our own analysis of the BRAF-related gene expression profile, which was performed on 49 PTC patients, confirmed the differences between BRAF-positive and both RET/PTC-positive and all no-BRAF cancers; the meta-analysis of our and Giordano's study is presented in Fig. 1. Surprisingly, a comparison of the genes selected on the basis of our study and those listed by Giordano $e t$ al. showed only 11 common genes in the $B R A F$ versus $R E T$ comparison (D Rusinek, M Oczko-Wojciechowska, M Kowalska, M Świernak, M Jarząb, A Czarniecka, J Włoch, S Szpak-Ulczok, E Chmielik, D Lange, M Kowal, M Wiench, D Handkiewicz-Junak \& B Jarząb 2007, unpublished observations). This lack of overlap clearly indicates that large numbers of cases are needed for multivariate analysis.

Currently, the only multivariate analysis carried out considering the influence of the BRAF V600E mutation on $P T C$ gene expression was performed by Jo et al. (2006). Upregulation of the vascular endothelial growth factor ( VEGF) gene was observed in BRAF-positive PTCs even after adjustment for extrathyroidal PTC invasion, tumor stage, and nodal and distant metastasis $(P=0 \cdot 03)$. The authors concluded that the over-expression of $V E G F$ in association with the $B R A F$ mutation might account for the high rate of recurrences and aggressive phenotype of PTC as well as its poor outcome.
Platelet-derived growth factor (PDGF; Wang et al. 2008) is among the highly upregulated genes in papillary thyroid carcinomas induced by the $B R A F$ V600E mutation, and its over-expression in thyroid neoplasms (Yano et al. 2004) and its presence in other tumors (Terrile et al. 2010) have been reported earlier. The receptor for PDGF - PDGFRB - is able to activate the ERK1/2 signaling through cross talk with other PDGFRB-induced pathways (Jurek et al. 2011). Moreover, Wang et al. (2008) observed a correlation between the presence of the BRAF V600E mutation and high platelet count, which is similar to the BRAF mutation itself, and was significantly associated with extrathyroidal invasion.

Many other genes were also associated with the presence of mutated BRAF. Franzoni et al. (2009) showed that prohibitin $(P H B)$ was over-expressed only in PTCs harboring the $B R A F$ mutation. Transfection of a $B R A F$ V600E construct resulted in an increase in $P H B$ promoter activity and higher expression of the protein product. PHB may act as tumor suppressor or exhibit a permissive influence on tumor growth.

In their search for $B R A F$-related transcriptome changes, Nucera et al. (2010) attempted to identify a PTC progression-related gene signature. Using a gene set enrichment analysis, they selected 18 gene sets significantly associated with the presence of

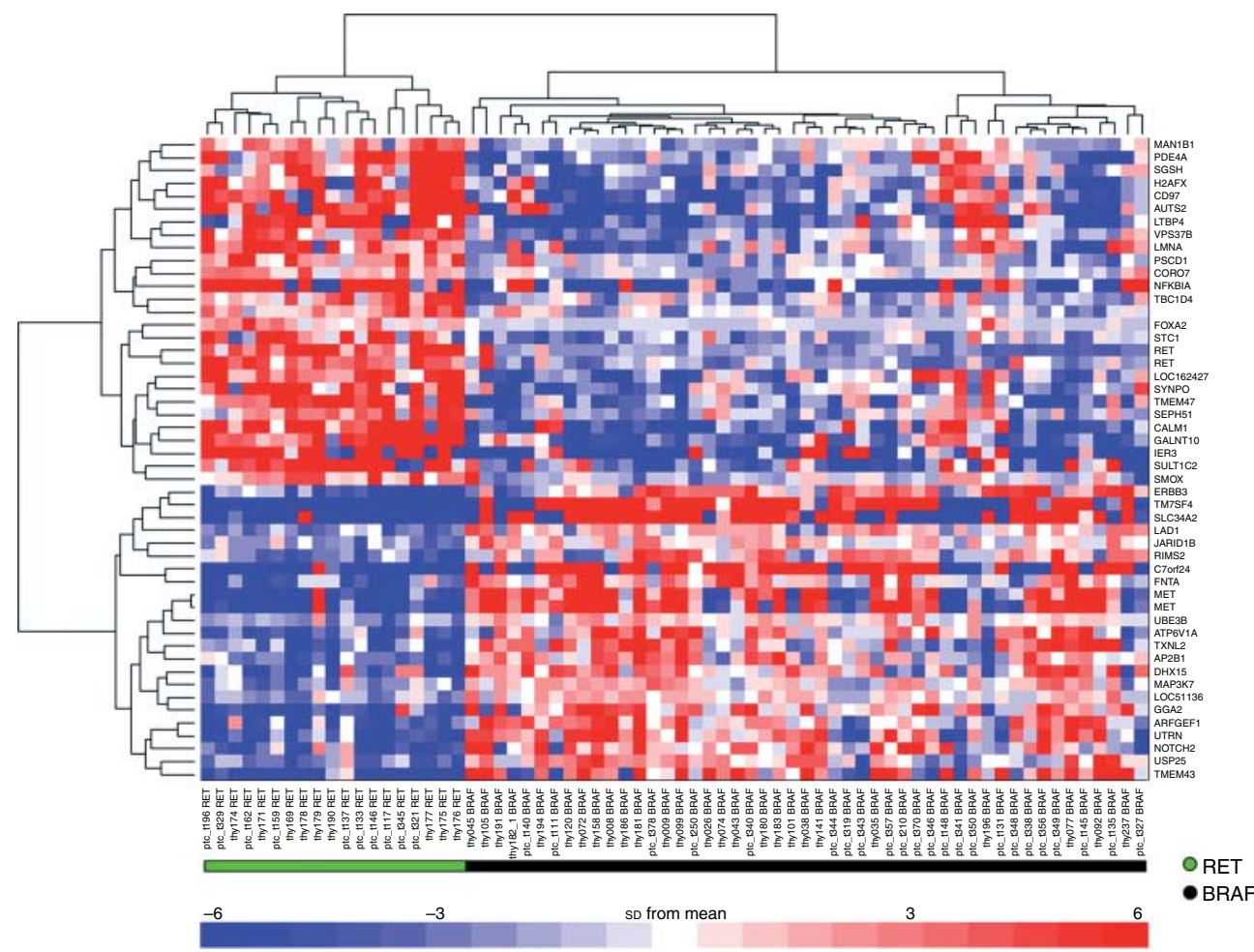

Figure 1 Comparison of gene expression profiles of BRAF(+) PTCs to RET(+) PTCs (analysis performed by combining our data and those of Giordano et al.). 
$B R A F$ mutation and identified one set of downregulated genes involved in cell polarity, indicating the importance of $B R A F \mathrm{~V} 600 \mathrm{E}$ in cell dedifferentiation. Comparison of BRAF-positive PTCs with controls led to the identification of many extracellular matrix genes related to the presence of $B R A F$. In their study, Nucera et al. focused on thrombospondin 1 (TSP1), a multifunctional matricellular protein that binds to many integrins and other matrix proteins, one among them being fibronectin 1, which is abundant in tumor stroma. Knockdown of the BRAF V600E gene led to a decrease in the TSP1 expression that was associated with a reduction in the migration/invasion phenotype of tumor cells both in vitro and in vivo.

The mechanism of cancer invasion in PTC is not well understood. Riesco-Eizaguirre et al. (2009) concluded that PTC invasion, which is more distinct in BRAFpositive PTCs, is TGF $\beta /$ Smad dependent. Gene expression analysis (Vasko et al. 2007) of microdissected intratumoral samples from central and invasive regions of invasive PTCs and normal thyroid tissue showed an upregulation of $T G F \beta, N F K B$, integrin pathway members, and $C D C 42$ in the invasive regions. Interestingly, the downregulation of a subset of mRNAs encoding proteins related to the epithelial to mesenchymal transformation (EMT) and involved in cell-cell adhesion and communication was observed in invasive PTCs. Vasko et al. proposed an association between CDC42/PAK signaling and the mechanisms of PTC invasion. In opposition to their results, Watanabe $e t$ al. (2009) performed a QPCR analysis to show a positive correlation between the BRAF V600E mutation and over-expression of vimentin, which was confirmed using NPA cells (inhibition of BRAF expression decreased vimentin levels). These authors also showed the $B R A F$ V600E-dependent upregulation of fibronectin and CITED1, both of which have been identified as PTC markers. The role of fibronectin 1 as a biomarker was first shown by QPCR and immunohistochemistry (Takano et al. 1998) and later by microarray analysis (Huang et al. 2001, Jarzab et al. 2005), while the role of CITED1 as a biomarker was first shown by microarray analysis (Huang et al. 2001) followed by immunohistochemistry (Prasad et al. 2004). Fibronectin 1, an adhesion-related gene, is considered a part of the EMT signature (Huang et al. 2001). CBP/p300-interacting transactivators with glutamic acid (E) / aspartic acid (D)rich C-terminal domain (CITED1) is a transcriptional coactivator initially identified in melanoma and known to interact with $S M A D 4 C, C P B / p 300$, and the estrogen receptor (de Caestecker et al. 2000, Yahata et al. 2000).

In this context, it is noteworthy that mutations of the BRAF gene, the $\mathrm{V} 600 \mathrm{E}$ mutation being the most frequent, are not the only characteristics of PTC. They are found in about $60 \%$ of melanomas (also in benign nevi), in a subset of lung, ovarian, and colon cancers and in childhood astrocytomas (Thomas 2006, Estep et al. 2007, Pratilas et al. 2008, Yousem et al. 2008, Farina-Sarasqueta et al. 2010, Schiffman et al. 2010). Interestingly, in nearly all these tumor localizations, the presence of the $B R A F$ mutation is related to a rather better prognosis. Comparative studies of the $B R A F$ gene expression signature in various tumor types may help to elucidate the relationship between the transcriptional consequences of its presence and the invasive tumor potential.

\section{The miRNA expression profile of papillary thyroid cancer and its relation to BRAF mutations}

Differences in gene expression profile related to the mutational status of PTC may be visible not only at the mRNA level but also at the level of the non-coding RNAs. In this context, Yoon et al. (2007) identified a novel non-coding RNA gene called NAMA, which is associated with the MAP kinase pathway and growth arrest, physiologically expressed in the testis and underexpressed in the BRAF-positive PTC.

Several authors have examined the differences in the levels of miRNAs between BRAF-positive and BRAFnegative PTCs and have shown contradicting results. Cahill et al. (2007) reported a unique miRNA expression signature in the cell lines with $B R A F$ mutation in comparison to the normal thyroid cell line, showing 15 upregulated miRNAs and 23 downregulated miRNAs. Sheu et al. (2009), however, did not detect any significant differences between BRAFpositive and BRAF-negative human PTCs, although their study was limited to a subset of five miRNAs. Chou et al. (2010) compared the levels of three miRNAs known to be over-expressed in PTC. A significantly higher expression of miR-146b was detected in BRAFpositive PTC, while miR-221 and miR-222, also shown to be related to a more aggressive tumor behavior, did not exhibit any difference in comparison to BRAF-negative tumors. Aherne et al. (2008) analyzed different fragments of one multifocal thyroid cancer and described miRNA profiles distinguishing tumors containing the BRAF mutation from other tumor types (with insular or anaplastic phenotype).

\section{$R E T / P T C$ rearrangements and their relation to gene expression in PTC}

$R E T / P T C$ rearrangements arise from the fusion of the $3^{\prime}$ end of the RET gene that encodes the tyrosine kinase domain with the $5^{\prime}$ domain of one of the several constitutively expressed genes. To date, 12 fusion genes and 15 different RET/PTC rearrangements have been described (Mishra et al. 2009), and the RET/PTC1 and $R E T / P T C 3$ are the most frequent rearrangements. 
RET/PTC1 and RET/PTC3 are paracentric inversions because both $R E T$ and its respective fusion partner $H 4$ or NCOA4 (also called ELE1; RFG and ARA70) are localized on the long arm of chromosome 10 (Grieco et al. 1990, Santoro et al. 1994). RET/PTC3 rearrangements were initially thought to be related to radiationinduced thyroid cancer (Rabes et al. 2000, Maenhaut et al. 2011). Now it is clear that they are characteristic of short latency PTC that develops in young persons, while $R E T / P T C 1$ prevails in long latency PTC (Williams et al. 2004). In fact, $R E T / P T C$ rearrangements are quite frequent both in radiation-induced and in sporadic pediatric PTC. They are found in $50-70 \%$ of cases of children with sporadic PTC, while they are rare in older PTC patients, especially after the 45 th year of age. The unique RET/PTC-related gene expression profile is less well characterized than that related to the $B R A F$ status. Frattini et al. (2004) were the first to identify a subset of genes differentially expressed in PTCs carrying receptor tyrosine kinase-related rearrangements by analyzing RET/PTC and NTRK1-mutated PTCs and comparing them to tumors with $B R A F$ mutation. Giordano et al. (2005), who constructed a simple multigene classifier, were able to recognize an additional RET/PTC-positive tumor sample without knowing its mutational status by its gene expression profile only. The gene expression signatures that differed in BRAF, RET/PTC, and RAS tumors included genes whose changed expression was a direct consequence of mutation (of RET/PTC rearrangement) as well as other genes involved in the immune response, signal transduction, and other processes. The hypothesis that different downstream pathways are activated by $R E T / P T C$ was supported by Miyagi et al. (2004), who used cell culture experiments to show that RET/PTC3 mutants signaled preferentially through the PI3K pathway compared to MAPK. Among the genes involved in signal transduction, besides ERBB3, MET, or DAPP1, VAV3 deserved attention as a phosphoinositol-3-kinase pathway-related gene responsible for $A K T$ activation that was preferentially expressed in PTCs with RET and RAS alterations.

Interestingly, the above-mentioned study of Mesa et al. (2006) on the early consequences of the $B R A F$ V600E mutation and RET/PTC3 rearrangement activation in rat thyroid PCCL3 cells revealed that the number of $R E T / P T C 3$-dependent genes was almost twice as high as that of genes activated by the $B R A F$ mutation. In total, only $25 \%$ of genes, all related to the MAPK pathway, were co-regulated by these two genetic alterations. Among those genes regulated by $R E T / P T C$ that did not need the activation of the $B R A F$ gene, there were many genes associated with the immune response, including the IFN (interferon) pathway genes. This was not the conclusion in Giordano's paper or in our own $B R A F$-related gene expression analysis of PTC (D Rusinek, M Oczko-Wojciechowska, M Kowalska,
M Świernak, M Jarząb, A Czarniecka, J Włoch, S SzpakUlczok, E Chmielik, D Lange, M Kowal, M Wiench, D Handkiewicz-Junak \& B Jarząb 2007, unpublished observations), but the number of $R E T / P T C$-dependent genes could be underestimated because of the lower number of RET/PTC-positive than BRAF-positive tumors.

\section{Expression of thyroid-specific genes in relation to different mutations in PTC}

The expression of key genes involved in thyroid hormone biosynthesis is known to be deregulated in thyroid cancer compared to normal thyroid tissue. The downregulation of the TSH receptor $(T S H R), N I S$, apical iodide transporter (SLC5A8), thyroperoxidase (TPO), and thyroglobulin as well as impaired NIS trafficking to the cell membrane was observed in papillary thyroid carcinomas, both with and without the BRAF mutation (Durante et al. 2007, Espadinha et al. 2009b). Simultaneously, the degree of dedifferentiation was higher in the BRAF-positive tumors. The loss of thyroid hormone production ability in PTC with the $B R A F$ mutation was accompanied by the increased expression of the glucose transporter 1 (GLUT1), which reflects the V600E potential to induce the dedifferentiation processes (Durante et al. 2007, Puxeddu \& Moretti 2007).

When comparing the wild-type BRAF PTCs with papillary thyroid carcinomas harboring the $\mathrm{V} 600 \mathrm{E}$ mutation, the NIS transcript levels in the BRAF-positive PTC were about five times lower than those observed in the BRAF-negative tumors, with even more distinct differences at the level of protein expression (almost ten times lower; Durante et al. 2007). Romei et al. (2008) observed that the number of NIS-positive cells was significantly lower in BRAF-positive tumors (53.5 vs $72 \cdot 6 \%$, while at the mRNA level, the difference was seen both in the NIS and in the TPO genes. Investigating the differences related to the $B R A F$ mutation in PTC, Riesco-Eizaguirre et al. (2009) analyzed the $B R A F$-induced secretion of functional TGF $\beta$, which repressed the NIS expression by the activation of Smad. This mechanism has been shown to be MAPK-ERK kinase independent. In the interpretation of these results, it is important that not only the expression level but also the localization of the transporter is crucial for its function. In both BRAFpositive and BRAF-negative PTCs, the expression of the NIS protein was mainly limited to the cytoplasm and was less observed at the cell membrane.

The lower SLC5A8 expression in the BRAF-associated PTCs is due to gene methylation (Porra et al. 2005). This thyroid-specific gene, unlike pendrin and NIS, is not TSH dependent. It is involved in the passive transport of iodide from the thyrocytes to the follicle lumen and was shown to be downregulated (40-fold) in the classical variant of papillary thyroid carcinoma 
(CV-PTC). The decreased expression of SLC5A8 is a consequence of exon 1 methylation, which is seen in 90\% of CV-PTC. This epigenetic change silencing SLC5A8 is also observed in colon cancer, where it occurs in the early stage of cancer development (Li et al. 2003). In thyroid carcinoma, methylation of SLC5A8 is related to the later stages of cancer progression. A significant correlation between the presence of the $B R A F$ V600E mutation and silencing of the SLC5A8 suggests that methylation occurs as a secondary event to BRAF-mutated initiation of the MAPK pathway.

\section{Gene expression changes common to all papillary thyroid cancer cases}

The differences in gene expression between primary PTC and normal thyroid tissue are significant and encompass thousands of genes (Jarzab et al. 2005, Fujarewicz et al. 2007). The rather homogenous gene expression profile of PTC surprised the authors of the first microarray-based investigation (Huang et al. 2001). However, it seems less unexpected if one considers that different mutations activate the MAPK-ERK cascade and cause similar downstream molecular and functional effects. Many gene expression changes triggered by neoplastic transformation are not only common to all PTC but are also seen in follicular thyroid cancer (FTC; Polanski et al. 2007) and adenocarcinomas in general or even in all malignant tumors (Rhodes et al. 2004, Polanski et al. 2007).

\section{Transcriptome of FTC}

The biology of FTC and its gene expression profile is much less known in comparison with PTC (Cerutti et al. 2003, Weber et al. 2005, Cerutti 2007, Hinsch et al. 2009). The underlying molecular alterations of FTC encompass either activating $R A S$ mutations (present in most cases already on the adenoma level) or PAX8/ peroxisome proliferator-activated receptor $\gamma(P P A R \gamma)$ rearrangements, which are more frequent at the carcinoma level (Knauf et al. 2006, Placzkowski et al. 2008). The oncocytic variant of follicular carcinoma expresses a very characteristic gene expression profile related to the presence of abundant mitochondria (Barden et al. 2003, Finley et al. 2004b, Baris et al. 2005).

\section{RAS-related changes in the gene expression of FTC and other thyroid tumors}

$R A S$ point mutations that activate the protein product are typical of follicular thyroid adenomas (FA) and FTC, showing a frequency range nearly $50 \%$ in both types of tumors. Because they are found at equal frequency in FAs and FTCs, RAS mutations are considered an early event in follicular neoplasia (Garcia-Rostan et al. 2003). There is no unequivocal proof of a larger tendency of RASpositive follicular adenomas to progress to follicular carcinomas, especially since nothing is known about the molecular events responsible for the further malignant transformation of a RAS-positive follicular adenoma. $P A X 8 / P P A R \gamma$ rearrangements occur preferentially in RAS-negative follicular tumors (Nikiforova et al. 2003b).

Surprisingly, the RAS-related signature of FTC is not well specified, possibly because it is not easily detected at the mRNA level. The impact of the RAS mutation on the gene expression of thyroid cells was studied using the FRTL-5 rat thyroid epithelial-derived cell line infected with the Kirsten murine sarcoma virus carrying the v-Ki-Ras oncogene (Visconti et al. 2007). Genes that were found to be significantly altered in RAS-transfected cells were validated by QPCR and studied in thyroid cancer cell lines of follicular cell carcinoma origin (WRO), papillary carcinoma origin (FB-2, NPA, TPC-1, and B-CPAP), and from anaplastic cancer (FRO and ARO). Annexin $\mathrm{A} 2$ and $R A L A$ (v-ral simian leukemia viral oncogene homolog A, RAS related) were upregulated in the RAS-transfected rat cells and positively validated in all seven cancer lines. Dual-specificity phosphatase 1 (DUSP1) and small cell lung carcinoma cluster 4 antigen (CD24) were downregulated by RAS in rat cells and also in all studied cancer cell lines (Rodrigues et al. 2007a).

$R A S$ mutations are found in $0-15 \%$ of PTCs (Vasko et al. 2003, Abrosimov et al. 2007, Hou et al. 2007), mostly as activating mutations of codons 12 and 13 of the NRAS gene, and showing higher incidence in follicular variant of PTC (Vasko et al. 2003, Zhu et al. 2003, Castro et al. 2006, Di Cristofaro et al. 2006, Goutas et al. 2008). RAS mutations have also been reported to be frequent in poorly differentiated thyroid cancer (PDTC; Garcia-Rostan et al. 2003, Riesco-Eizaguirre \& Santisteban 2007, Volante et al. 2009). However, the distinct gene expression profile differences between PTC and PDTC are related to the grade of differentiation itself rather than to the presence of different initiating mutations (Fluge et al. 2006). However, Pita et al. (2009) reported similarities between the follicular variant of PTC and the RAS-mutated PDTC.

\section{Gene signature of the PAX8/PPAR $\gamma$ rearrangement}

PAX8/PPAR $\gamma$ translocations (PAX8/PPAR $\gamma$ fusion protein, PPFP) are present in $26-56 \%$ of FTCs and also in a number of FAs. This kind of translocation generates a fusion oncoprotein that acts as a dominant negative inhibitor of wild-type PPAR $\gamma$ and has unique transcriptional activity when compared with wild-type PAX8 or PPAR $\gamma$. Lacroix et al. (2005) revealed a pattern 
of 93 genes that discriminated FTCs with and without translocation, which at the morphological level were indistinguishable. PPAR $\gamma$-dependent genes were overexpressed in FTCs bearing the translocation, including angiopoietin-like 4 , aquaporin 7 , or a potential target FGD3. No differences in the expression of thyroidspecific genes were noted. In addition, Giordano et al. (2006) reported that the presence of this balanced translocation is associated with a specific gene expression signature, which is composed of known PPAR target genes involved in fatty acid metabolism such as carnitine/acylcarnitine translocase (SLC25A20) and acetyl-CoA acyltransferase 1 (ACAA1), amino acid and carbohydrate metabolism, and specific micro-RNA target genes. Among the top, 20\% of genes highly upregulated in PPFP-positive FTCs were genes detected on chromosome 3p (95 from 341 genes). Four miRNAs were strongly over-expressed in FTCs harboring PAX8/PPAR $\gamma$ rearrangement: miR-101, miR-30A-3P, miR-200A, and miR-199A. The authors found 21 upregulated genes that were potential targets for at least three of the above-mentioned miRNAs, including oncogenes like RUNX1/AML1 and SS18.

\section{Other molecular events characterizing FTC and not related to its mutational status}

The majority of the gene expression analyses of FTC (Barden et al. 2003, Cerutti et al. 2004, Finley et al. 2004a, Weber et al. 2005, Hinsch et al. 2009) have considered the diagnostic aspect and have searched for gene signatures or genes differentiating FTC from FA. Among the genes listed are cyclin D2, protein convertase 2 (PCSK2), and prostate differentiation factor (PLAB; Borup et al. 2010). Borup et al. performed a global expression profiling of follicular tumors and found expression changes in genes involved in DNA replication and mitosis, loss of growth arrest, and proapoptotic factors to be characteristic of FTC, among them being $N R 4 A 1$ and $A 3$, encoding orphan nuclear receptors involved in the regulation of proliferation and apoptosis, as well as FOSB and JUN. Loss of apoptosis and growth arrest factors occurred during malignant transformation and was prominent in all samples, implying that this event preceded proliferation. The coordinated downregulation of the expression of NR4A1 and A3, JUN, FOSB, and CITED2 was a striking observation for these authors because it was contrary to their increased expression in other cancers. Interestingly, $N R 4 A 1$ and $A 3$ translocate to the mitochondria, where they stimulate the release of cytochrome $\mathrm{C}$ in a BLC2-dependent manner (Borup et al. 2010). The frequent loss of expression had been reported as a characteristic feature of FTC previously. The self-regulation of caveolin-1, both at the mRNA and protein levels, was one of the first expression changes described in FTCs by Aldred et al. (2003), who also considered insular-type and oxyphilic (Hurthle-type) thyroid cancers.

\section{Transcriptome of PDTC and undifferentiated thyroid cancer in relation to their mutational profile}

The PDTC and undifferentiated anaplastic thyroid carcinomas (ATC) respectively present a much more aggressive clinical course than papillary or follicular thyroid cancers, which are frequently described as welldifferentiated cancers (DTC). Their origin is not well defined but the prevalence of $B R A F, R A S$ mutations, or genetic alterations of PIK $3 C A$ as well as the presence of pre-existing PTC areas observed in some PDTCs suggest that at least some of them may originate from DTCs (Garcia-Rostan et al. 2003, 2005, Nikiforova et al. 2003a). In addition, RET/PTC rearrangements were detected in PDTCs at a frequency of $10 \%$, and the proportion increased to $20 \%$ when only PDTCs with areas of welldifferentiated thyroid carcinoma were considered (Santoro et al. 2002). Although a mouse model of papillary thyroid carcinoma induced by RET/PTC3 showed the formation of a solid PTC variant with metastases (Powell et al. 1998), there is no evidence of the association between $R E T / P T C$ and poor prognosisassociated PDTCs (Santoro et al. 2002). Wreesmann et al. (2002) noticed an increase in the incidence of DNA copy number changes from DTC to PDTC, both at the level of number of patients with abnormalities and number of abnormalities per case. Saltman et al. (2006) suggested an intermediate position for PDTC between the well-differentiated and anaplastic thyroid carcinomas, with the most significant changes represented by the Ki- 67 protein, which was present in $5.8 \%$ of welldifferentiated PTC, $48.8 \%$ of PDTCs, and $81.8 \%$ of ATCs. Nevertheless, the hypothesis that PDTC and ATC arise de novo cannot be excluded.

The deregulation of TP53 (tumor protein p53) and Wnt pathways and mutations of $\beta$-catenin are common in both PDTC and ATC (Donghi et al. 1993, GarciaRostan et al. 1999). Lavra et al. (2009) showed a positive correlation between galectin-3 expression and p53 mutations. Gal-3, an adhesion-related and simultaneously anti-apoptotic molecule, was upregulated in most ATCs and thyroid carcinoma cell lines harboring the most frequently detected $p 53$ mutation, R273H. Over-expression of the p53 protein (TP53) was also found to be correlated with the upregulation of its antagonist p63, a member of the p53 protein family (Malaguarnera et al. 2005) and the GLUT1 (Kim et al. 2006). Schwartzenberg-Bar-Yoseph et al. (2004) demonstrated that GLUT1 and GLUT4 are repressed by wildtype p53, and mutations within the DNA-binding 
domain of TP53 disable this interaction. These data help to explain the findings of Kim et al. (2006) showing over-expression of TP53 and GLUT1 in ATC. Guida et al. suggested dependency between mutated TP53 and upregulation of minichromosome maintenance protein 7 (MCM7), a protein required for DNA replication, which was reported to be highly overexpressed in ATC but absent in normal thyroid and PTC (Guida et al. 2005).

Salvatore et al. (2007) presented a gene signature of anaplastic thyroid carcinoma characterized by the upregulation of genes involved in the regulation of cell cycle progression and chromosome segregation. The authors demonstrated that the Polo-like kinase 1 (PLK1), previously included in the 'proliferation cluster' and 'chromosomal instability 70 cluster' (Tabach et al. 2005, Carter et al. 2006, Whitfield et al. 2006), was required for ATC cell proliferation and cell survival, and this dependence was not detected in normal thyroid cells, in agreement with the data of Nappi et al. (2009). Pita et al. (2009) found a number of upregulated cell cycle-related genes in PDTC. Among them were genes associated with mitosis such as CDC28 protein kinase regulatory subunit 2 (CKS2) and cyclin E2 (CCNE2), which were previously reported as upregulated in many other types of tumors (Gudas et al. 1999, Scrideli et al. 2008). The authors stressed the overexpression of the ubiquitin-like, containing PHD and ring finger domains (UHFRl) gene in PDTC. This gene encodes a protein involved in processes of breaking and rejoining of DNA strands through the regulation of the TOP2A enzyme and is involved in the DNA damage response and, through the regulation of methyltransferase 1 (DNMT1), in VEGF regulation. The UHFR1 gene is located within the chromosome region 19p13, in which Lee et al. (2008) by CGH-array reported gains in 67\% of ATCs. Microarray analysis also showed a strong upregulation of PKB (v-AKT murine thymoma viral oncogene homolog 1), which encodes a serine/threonine kinase of the MAPK pathway, in PDTC. The over-expression of $P K B$ in poorly differentiated thyroid carcinomas was first demonstrated by Rodrigues et al. (2007b), who emphasized the importance of the MAP kinase pathway in the progression of thyroid carcinomas. Montero-Conde et al. (2008) investigated differentiated and undifferentiated thyroid tumors by using cDNA microarrays and also reported significant changes in the expression of genes of the MAPK pathway, as well as those of the TGF $\beta$ pathway, focal adhesion, and activation of actin polymerization and cell cycle.

Ito et al. (2009) reported the co-expression of S100A8 and A100A9, which represent the $\mathrm{S} 100$ calcium-binding proteins $\mathrm{A} 8$ and $\mathrm{A} 9$, in undifferentiated thyroid carcinomas, and the lack of S100A8 expression and a weak expression of S100A9 in PDTC, and lack of these proteins in well-differentiated DTC. Similar gradation was reported by Aratake $e t$ al. (2010) who examined the expression of extracellular matrix metalloproteinase inducer (EMMPRIN) and found a weak expression level in welldifferentiated DTC $(4 \cdot 9)$ and high levels in ATC $(245 \cdot 7)$.

With regard to genes downregulated (lost) in ATC, Rodrigues et al. (2007b) reported the downregulation of pleomorphic adenoma gene-like 1 (PLAGL1) and described under-expression of $C D H 1$ (cadherin 1, type 1, E-cadherin (epithelial)) in PDTC. Most downregulated genes described by Pita $e t$ al. in PDTC in comparison to normal thyroid tissue were related to cell adhesion. Deregulation of cell adhesion genes may promote tumor invasion and metastasis. However, there were only two genes differentially expressed when PDTC was compared to DTC, and 3-phosphoinositide-dependent protein kinase-1 gene (PDPK1) was the most interesting gene with regard to its function in AKT activation. Downregulation of the epithelial cell adhesion molecule (EpCAM) was reported by Ensinger et al. (2006), who reported its absence from undifferentiated thyroid carcinomas and high level of EpCAM expression in well-differentiated DTC and PDTC. Previous studies indicated the dual role of EpCAM, suggesting its association with tumor formation and oncogene characteristics (Spizzo et al. 2004). However, another study also described EpCAM as a tumor suppressive protein (Gosens et al. 2007). Because of the adhesive properties of EpCAM (Litvinov et al. 1994), a role of this protein in the inhibition of invasion was proposed.

Espadinha et al. (2009a) reported an association between the downregulation of PPAR $\gamma$ and lower differentiation of thyroid follicular cells. These authors focused on the effect of PPAR $\gamma$ on the function of E2F/DP, which regulates the expression of genes involved in entry into $\mathrm{S}$ phase and DNA synthesis and whose decrease was observed during the differentiation of several types of cells (La Thangue and Rigby 1987, Hara et al. 1993, Melamed et al. 1993).

With reference to miRNA expression in undifferentiated thyroid cancers, Visone et al. (2007) suggested that the deregulation of miRNA might be an important step in thyroid carcinogenesis based on the detection of a decrease in miR-30d, miR-125b, miR-26a, and miR30a-5p in ATC compared with normal thyroid tissue. Not unexpectedly, the array-based analyses showed a marked under-expression of thyroid-specific genes in anaplastic thyroid carcinoma (Onda et al. 2004, Rodrigues et al. 2007b, Matsumoto et al. 2008).

\section{Final remarks}

The relationship between the presence of thyroid cancer histotype-specific mutations and the gene expression profiles of tumors is complex, and many factors related to cancer invasiveness and host 
responses have to be considered. However, studies on the association of gene signatures with mutational events associated with carcinogenesis may help to elucidate the molecular consequences of the activation of oncogenes and the loss of tumor suppressors and thus improve our understanding of tumor biology and facilitate the search for prognostic and predictive markers and new therapy targets. The gene expression profile differences between papillary thyroid cancer and FTC and PDTC and undifferentiated thyroid cancer mainly reflect the differences in the degree of tumor differentiation. However, the observed profound differences between BRAF-positive and BRAF-negative PTCs, much more distinct than the respective differences in the gene expression signatures of FTCs with different mutations, are indicative of profound changes in biology related to the appearance of this particular oncogene.

\section{Declaration of interest}

The authors declare that there is no conflict of interest that could be perceived as prejudicing the impartiality of this review.

\section{Funding}

This work was supported by the 6th Framework Project Genrisk-T (036495).

\section{References}

Abrosimov A, Saenko V, Rogounovitch T, Namba H, Lushnikov E, Mitsutake N \& Yamashita S 2007 Different structural components of conventional papillary thyroid carcinoma display mostly identical BRAF status. International Journal of Cancer 120 196-200. (doi:10. 1002/ijc.22290)

Aherne ST, Smyth PC, Flavin RJ, Russell SM, Denning KM, Li JH, Guenther SM, O'Leary JJ \& Sheils OM 2008 Geographical mapping of a multifocal thyroid tumour using genetic alteration analysis \& miRNA profiling. Molecular Cancer 7 89. (doi:10.1186/1476-45987-89)

Aldred MA, Ginn-Pease ME, Morrison CD, Popkie AP, Gimm O, Hoang-Vu C, Krause U, Dralle H, Jhiang SM, Plass C et al. 2003 Caveolin-1 and caveolin-2 together with three bone morphogenetic protein-related genes, may encode novel tumor suppressors downregulated in sporadic follicular thyroid carcinogenesis. Cancer Research 63 2864-2871.

Aratake Y, Marutsuka K, Kiyoyama K, Kuribayashi T, Miyamoto T, Yakushiji K, Ohno S, Miyake Y, Sakaguchi T, Kobayashi TK et al. 2010 EMMPRIN (CD147) expression and differentiation of papillary thyroid carcinoma: implications for immunocytochemistry in FNA cytology. Cytopathology 21 103-110. (doi:10.1111/j.1365-2303.2009. 00716.x)

Barden CB, Shister KW, Zhu B, Guiter G, Greenblatt DY, Zeiger MA \& Fahey TJ III 2003 Classification of follicular thyroid tumors by molecular signature: results of gene profiling. Clinical Cancer Research 9 1792-1800.

Baris O, Mirebeau-Prunier D, Savagner F, Rodien P, Ballester B, Loriod B, Granjeaud S, Guyetant S, Franc B, Houlgatte R et al. 2005 Gene profiling reveals specific oncogenic mechanisms and signaling pathways in oncocytic and papillary thyroid carcinoma. Oncogene $\mathbf{2 4}$ 4155-4161. (doi:10.1038/sj.onc.1208578)

Borup R, Rossing M, Henao R, Yamamoto Y, Krogdahl A, Godballe C, Winther O, Kiss K, Christensen L, Hogdall E et al. 2010 Molecular signatures of thyroid follicular neoplasia. Endocrine-Related Cancer $\mathbf{1 7}$ 691-708. (doi:10.1677/ERC-09-0288)

de Caestecker MP, Yahata T, Wang D, Parks WT, Huang S, Hill CS, Shioda T, Roberts AB \& Lechleider RJ 2000 The Smad4 activation domain $(\mathrm{SAD})$ is a proline-rich, p300-dependent transcriptional activation domain. Journal of Biological Chemistry 275 2115-2122. (doi:10.1074/jbc.275.3.2115)

Cahill S, Smyth P, Denning K, Flavin R, Li J, Potratz A, Guenther SM, Henfrey R, O'Leary JJ \& Sheils O 2007 Effect of BRAFV600E mutation on transcription and post-transcriptional regulation in a papillary thyroid carcinoma model. Molecular Cancer 6 21. (doi:10. 1186/1476-4598-6-21)

Carter SL, Eklund AC, Kohane IS, Harris LN \& Szallasi Z 2006 A signature of chromosomal instability inferred from gene expression profiles predicts clinical outcome in multiple human cancers. Nature Genetics 38 1043-1048. (doi:10.1038/ng1861)

Castro P, Rebocho AP, Soares RJ, Magalhaes J, Roque L, Trovisco V, Vieira de Castro I, Cardoso-de-Oliveira M, Fonseca E, Soares P et al. 2006 PAX8-PPAR gamma rearrangement is frequently detected in the follicular variant of papillary thyroid carcinoma. Journal of Clinical Endocrinology and Metabolism 91 213-220. (doi:10.1210/jc. 2005-1336)

Cerutti JM 2007 Nodule diagnosed as follicular patterned lesion: are biomarkers the promise? Arquivos Brasileiros de Endocrinologia e Metabologia 51 832-842. (doi:10.1590/S0004-27302007000500022)

Cerutti JM, Ebina KN, Matsuo SE, Martins L, Maciel RM \& Kimura ET 2003 Expression of Smad4 and Smad7 in human thyroid follicular carcinoma cell lines. Journal of Endocrinological Investigation 26 516-521.

Cerutti JM, Delcelo R, Amadei MJ, Nakabashi C, Maciel RM, Peterson B, Shoemaker J \& Riggins GJ 2004 A preoperative diagnostic test that distinguishes benign from malignant thyroid carcinoma based on gene expression. Journal of Clinical Investigation 113 1234-1242. (doi:10.1172/JCI19617)

Chou CK, Chen RF, Chou FF, Chang HW, Chen YJ, Lee YF, Yang KD, Cheng JT, Huang CC \& Liu RT 2010 miR-146b is highly expressed in adult papillary thyroid carcinomas with high risk features including extrathyroidal invasion and the BRAF(V600E) mutation. Thyroid 20 489-494. (doi:10.1089/thy.2009.0027)

Di Cristofaro J, Marcy M, Vasko V, Sebag F, Fakhry N, WynfordThomas D \& de Micco C 2006 Molecular genetic study comparing follicular variant versus classic papillary thyroid carcinomas: association of $N$-ras mutation in codon 61 with follicular variant. Human Pathology 37 824-830. (doi:10.1016/j.humpath.2006.01. 030)

Donghi R, Longoni A, Pilotti S, Michieli P, Della PG \& Pierotti MA 1993 Gene p53 mutations are restricted to poorly differentiated and undifferentiated carcinomas of the thyroid gland. Journal of Clinical Investigation 91 1753-1760. (doi:10.1172/JCI116385)

Durante C, Puxeddu E, Ferretti E, Morisi R, Moretti S, Bruno R, Barbi F, Avenia N, Scipioni A, Verrienti A et al. 2007 BRAF mutations in papillary thyroid carcinomas inhibit genes involved in iodine metabolism. Journal of Clinical Endocrinology and Metabolism 92 2840-2843. (doi:10.1210/jc.2006-2707)

Ensinger C, Kremser R, Prommegger R, Spizzo G \& Schmid KW 2006 EpCAM overexpression in thyroid carcinomas: a histopathological study of 121 cases. Journal of Immunotherapy 29 569-573. (doi:10. 1097/01.cji.0000211303.52503.da)

Espadinha C, Pinto AE \& Leite V 2009a Underexpression of PPARgamma is associated with aneuploidy and lower differentiation of thyroid tumours of follicular origin. Oncology Reports 22 907-913. (doi:10.3892/or_00000516) 
Espadinha C, Santos JR, Sobrinho LG \& Bugalho MJ $2009 b$ Expression of iodine metabolism genes in human thyroid tissues: evidence for age and BRAFV600E mutation dependency. Clinical Endocrinology 70 629-635. (doi:10.1111/j.1365-2265.2008.03376.x)

Estep AL, Palmer C, McCormick F \& Rauen KA 2007 Mutation analysis of BRAF, MEK1 and MEK2 in 15 ovarian cancer cell lines: implications for therapy. PLoS ONE 2 e1279. (doi:10.1371/journal. pone.0001279)

Eszlinger M \& Paschke R 2010 Molecular fine-needle aspiration biopsy diagnosis of thyroid nodules by tumor specific mutations and gene expression patterns. Molecular and Cellular Endocrinology 322 29-37. (doi:10.1016/j.mce.2010.01.010)

Eszlinger M, Krohn K, Kukulska A, Jarzab B \& Paschke R 2007 Perspectives and limitations of microarray-based gene expression profiling of thyroid tumors. Endocrine Reviews 28 322-338. (doi:10. 1210/er.2006-0047)

Fagin JA 2005 Genetics of papillary thyroid cancer initiation: implications for therapy. Transactions of the American Clinical and Climatological Association 116 259-269.

Fagin JA, Matsuo K, Karmakar A, Chen DL, Tang SH \& Koeffler HP 1993 High prevalence of mutations of the p53 gene in poorly differentiated human thyroid carcinomas. Journal of Clinical Investigation 91 179-184. (doi:10.1172/JCI116168)

Farina-Sarasqueta A, van Lijnschoten G, Moerland E, Creemers GJ, Lemmens VE, Rutten HJ \& van den Brule AJ 2010 The BRAF V600E mutation is an independent prognostic factor for survival in stage II and stage III colon cancer patients. Annals of Oncology 21 2396-2402. (doi:10.1093/annonc/mdq258)

Finley DJ, Zhu B, Barden CB \& Fahey TJ III 2004a Discrimination of benign and malignant thyroid nodules by molecular profiling. Annals of Surgery 240 425-436. (doi:10.1097/01.sla.0000137128. 64978.bc)

Finley DJ, Zhu B \& Fahey TJ III $2004 b$ Molecular analysis of Hurthle cell neoplasms by gene profiling. Surgery 136 1160-1168. (doi:10. 1016/j.surg.2004.05.061)

Fluge O, Bruland O, Akslen LA, Lillehaug JR \& Varhaug JE 2006 Gene expression in poorly differentiated papillary thyroid carcinomas. Thyroid 16 161-175. (doi:10.1089/thy.2006.16.161)

Franzoni A, Dima M, D'Agostino M, Puppin C, Fabbro D, Loreto CD, Pandolfi M, Puxeddu E, Moretti S, Celano M et al. 2009 Prohibitin is overexpressed in papillary thyroid carcinomas bearing the BRAF(V600E) mutation. Thyroid 19 247-255. (doi:10.1089/thy. 2008.0235)

Frasca F, Nucera C, Pellegriti G, Gangemi P, Attard M, Stella M, Loda M, Vella V, Giordano C, Trimarchi F et al. 2008 BRAF(V600E) mutation and the biology of papillary thyroid cancer. Endocrine-Related Cancer 15 191-205. (doi:10.1677/ERC-07-0212)

Frattini M, Ferrario C, Bressan P, Balestra D, De Cecco L, Mondellini P, Bongarzone I, Collini P, Gariboldi M, Pilotti S et al. 2004 Alternative mutations of BRAF, RET and NTRK1 are associated with similar but distinct gene expression patterns in papillary thyroid cancer. Oncogene 23 7436-7440. (doi:10.1038/sj.onc.1207980)

Fujarewicz K, Jarzab M, Eszlinger M, Krohn K, Paschke R, OczkoWojciechowska M, Wiench M, Kukulska A, Jarzab B \& Swierniak A 2007 A multi-gene approach to differentiate papillary thyroid carcinoma from benign lesions: gene selection using support vector machines with bootstrapping. Endocrine-Related Cancer 14 809-826. (doi:10.1677/ERC-06-0048)

Garcia-Rostan G, Tallini G, Herrero A, D’Aquila TG, Carcangiu ML \& Rimm DL 1999 Frequent mutation and nuclear localization of beta-catenin in anaplastic thyroid carcinoma. Cancer Research $\mathbf{5 9}$ 1811-1815.

Garcia-Rostan G, Zhao H, Camp RL, Pollan M, Herrero A, Pardo J, Wu R, Carcangiu ML, Costa J \& Tallini G 2003 Ras mutations are associated with aggressive tumor phenotypes and poor prognosis in thyroid cancer. Journal of Clinical Oncology 21 3226-3235. (doi:10. $1200 / J C O .2003 .10 .130$ )
Garcia-Rostan G, Costa AM, Pereira-Castro I, Salvatore G, Hernandez R, Hermsem MJ, Herrero A, Fusco A, Cameselle-Teijeiro J \& Santoro M 2005 Mutation of the PIK3CA gene in anaplastic thyroid cancer. Cancer Research 65 10199-10207. (doi:10.1158/0008-5472. CAN-04-4259)

Giordano TJ, Kuick R, Thomas DG, Misek DE, Vinco M, Sanders D, Zhu Z, Ciampi R, Roh M, Shedden K et al. 2005 Molecular classification of papillary thyroid carcinoma: distinct BRAF, RAS, and RET/PTC mutation-specific gene expression profiles discovered by DNA microarray analysis. Oncogene 24 6646-6656. (doi:10. 1038/sj.onc.1208822)

Giordano TJ, Au AY, Kuick R, Thomas DG, Rhodes DR, Wilhelm KG Jr, Vinco M, Misek DE, Sanders D, Zhu Z et al. 2006 Delineation, functional validation, and bioinformatic evaluation of gene expression in thyroid follicular carcinomas with the PAX8-PPARG translocation. Clinical Cancer Research 12 1983-1993. (doi:10.1158/ 1078-0432.CCR-05-2039)

Gosens MJ, van Kempen LC, van de Velde CJ, van Krieken JH \& Nagtegaal ID 2007 Loss of membranous Ep-CAM in budding colorectal carcinoma cells. Modern Pathology 20 221-232. (doi:10. 1038/modpathol.3800733)

Goutas N, Vlachodimitropoulos D, Bouka M, Lazaris AC, Nasioulas G \& Gazouli M 2008 BRAF and K-RAS mutation in a Greek papillary and medullary thyroid carcinoma cohort. Anticancer Research 28 305-308.

Grieco M, Santoro M, Berlingieri MT, Melillo RM, Donghi R, Bongarzone I, Pierotti MA, Della Porta G, Fusco A \& Vecchio G 1990 PTC is a novel rearranged form of the ret proto-oncogene and is frequently detected in vivo in human thyroid papillary carcinomas. Cell 60 557-563. (doi:10.1016/0092-8674(90)90659-3)

Gudas JM, Payton M, Thukral S, Chen E, Bass M, Robinson MO \& Coats S 1999 Cyclin E2, a novel G1 cyclin that binds Cdk2 and is aberrantly expressed in human cancers. Molecular and Cellular Biology 19 612-622.

Guida T, Salvatore G, Faviana P, Giannini R, Garcia-Rostan G, Provitera L, Basolo F, Fusco A, Carlomagno F \& Santoro M 2005 Mitogenic effects of the up-regulation of minichromosome maintenance proteins in anaplastic thyroid carcinoma. Journal of Clinical Endocrinology and Metabolism 90 4703-4709. (doi:10.1210/jc.20042459)

Handkiewicz-Junak D, Czarniecka A \& Jarzab B 2010 Molecular prognostic markers in papillary and follicular thyroid cancer: current status and future directions. Molecular and Cellular Endocrinology 322 8-28. (doi:10.1016/j.mce.2010.01.007)

Hara E, Okamoto S, Nakada S, Taya Y, Sekiya S \& Oda K 1993 Protein phosphorylation required for the formation of E2F complexes regulates $\mathrm{N}$-myc transcription during differentiation of human embryonal carcinoma cells. Oncogene 8 1023-1032.

Hinsch N, Frank M, Doring C, Vorlander C \& Hansmann ML 2009 QPRT: a potential marker for follicular thyroid carcinoma including minimal invasive variant; a gene expression, RNA and immunohistochemical study. BMC Cancer 9 93. (doi:10.1186/14712407-9-93)

Horndler C, Gallego R, Garcia-Albeniz X, Alonso-Espinaco V, Alonso V, Escudero P, Jimeno M, Ortego J, Codony-Servat J, Fernandez-Martos C et al. 2011 Co-expression of matrix metalloproteinase-7 (MMP-7) and phosphorylated insulin growth factor receptor I (pIGF-1R)): a GEMCAD study. Cancer Biology E Therapy 11 177-183. (doi:10.4161/ cbt.11.2.13839)

Hou P, Liu D, Shan Y, Hu S, Studeman K, Condouris S, Wang Y, Trink A, El-Naggar AK, Tallini G et al. 2007 Genetic alterations and their relationship in the phosphatidylinositol 3-kinase/Akt pathway in thyroid cancer. Clinical Cancer Research 13 1161-1170. (doi:10.1158/ 1078-0432.CCR-06-1125)

Huang Y, Prasad M, Lemon WJ, Hampel H, Wright FA, Kornacker K, LiVolsi V, Frankel W, Kloos RT, Eng C et al. 2001 Gene expression in papillary thyroid carcinoma reveals highly consistent profiles. PNAS 98 15044-15049. (doi:10.1073/pnas.251547398) 
Ito Y, Arai K, Nozawa R, Yoshida H, Hirokawa M, Fukushima M, Inoue H, Tomoda C, Kihara M, Higashiyama T et al. 2009 S100A8 and S100A9 expression is a crucial factor for dedifferentiation in thyroid carcinoma. Anticancer Research 29 4157-4161.

Jakubowski M \& Hunt JL 2009 BRAF mutational analysis in papillary carcinomas with mixed follicular and papillary growth patterns. American Journal of Surgical Pathology 33 1590-1593. (doi:10.1097/ PAS.0b013e3181b7c7ae)

Jarzab B, Wiench M, Fujarewicz K, Simek K, Jarzab M, OczkoWojciechowska M, Wloch J, Czarniecka A, Chmielik E, Lange D et al. 2005 Gene expression profile of papillary thyroid cancer: sources of variability and diagnostic implications. Cancer Research 65 1587-1597. (doi:10.1158/0008-5472.CAN-04-3078)

Jo YS, Li S, Song JH, Kwon KH, Lee JC, Rha SY, Lee HJ, Sul JY, Kweon GR, Ro HK et al. 2006 Influence of the BRAF V600E mutation on expression of vascular endothelial growth factor in papillary thyroid cancer. Journal of Clinical Endocrinology and Metabolism 91 3667-3670. (doi:10.1210/jc.2005-2836)

Jurek A, Heldin CH \& Lennartsson J 2011 Platelet-derived growth factor-induced signaling pathways interconnect to regulate the temporal pattern of Erk1/2 phosphorylation. Cellular Signalling 23 280-287. (doi:10.1016/j.cellsig.2010.09.013)

Karim R, Tse G, Putti T, Scolyer R \& Lee S 2004 The significance of the Wnt pathway in the pathology of human cancers. Pathology 36 120-128. (doi:10.1080/00313020410001671957)

Kim YW, Do IG \& Park YK 2006 Expression of the GLUT1 glucose transporter, p63 and p53 in thyroid carcinomas. Pathology, Research and Practice 202 759-765. (doi:10.1016/j.prp.2006. 07.006)

Kimura ET, Nikiforova MN, Zhu Z, Knauf JA, Nikiforov YE \& Fagin JA 2003 High prevalence of BRAF mutations in thyroid cancer: genetic evidence for constitutive activation of the RET/PTC-RAS-BRAF signaling pathway in papillary thyroid carcinoma. Cancer Research 63 1454-1457.

Klopfleisch R, Lenze D, Hummel M \& Gruber AD 2011 The metastatic cascade is reflected in the transcriptome of metastatic canine mammary carcinomas. Veterinary Journal (In Press). (doi:10.1016/j. tvil.2010.10.018)

Knauf JA, Ouyang B, Knudsen ES, Fukasawa K, Babcock G \& Fagin JA 2006 Oncogenic RAS induces accelerated transition through G2/M and promotes defects in the G2 DNA damage and mitotic spindle checkpoints. Journal of Biological Chemistry 281 3800-3809. (doi:10. 1074/jbc.M511690200)

Kondo T, Ezzat S \& Asa SL 2006 Pathogenetic mechanisms in thyroid follicular-cell neoplasia. Nature Reviews. Cancer 6 292-306. (doi:10. 1038/nrc1836)

Kouniavsky G \& Zeiger MA 2010 Thyroid tumorigenesis and molecular markers in thyroid cancer. Current Opinion in Oncology 22 23-29. (doi:10.1097/CCO.0b013e328333846f)

Lacroix L, Lazar V, Michiels S, Ripoche H, Dessen P, Talbot M, Caillou B, Levillain JP, Schlumberger M \& Bidart JM 2005 Follicular thyroid tumors with the PAX8-PPAR gamma 1 rearrangement display characteristic genetic alterations. American Journal of Pathology 167 223-231. (doi:10.1016/S0002-9440(10)62967-7)

La Perle KM, Jhiang SM \& Capen CC 2000 Loss of p53 promotes anaplasia and local invasion in RET/PTC1-induced thyroid carcinomas. American Journal of Pathology 157 671-677. (doi:10. 1016/S0002-9440(10)64577-4)

La Thangue NB \& Rigby PW 1987 An adenovirus E1A-like transcription factor is regulated during the differentiation of murine embryonal carcinoma stem cells. Cell 49 507-513. (doi:10. 1016/0092-8674(87)90453-3)

Lavra L, Ulivieri A, Rinaldo C, Dominici R, Volante M, Luciani E, Bartolazzi A, Frasca F, Soddu S \& Sciacchitano S 2009 Gal-3 is stimulated by gain-of-function p53 mutations and modulates chemoresistance in anaplastic thyroid carcinomas. Journal of Pathology 218 66-75. (doi:10.1002/path.2510)
Lee JJ, Au AY, Foukakis T, Barbaro M, Kiss N, Clifton-Bligh R, Staaf J, Borg A, Delbridge L, Robinson BG et al. 2008 Array-CGH identifies cyclin D1 and UBCH10 amplicons in anaplastic thyroid carcinoma. Endocrine-Related Cancer 15 801-815. (doi:10.1677/ERC-08-0018)

Li H, Myeroff L, Smiraglia D, Romero MF, Pretlow TP, Kasturi L, Lutterbaugh J, Rerko RM, Casey G, Issa JP et al. 2003 SLC5A8, a sodium transporter, is a tumor suppressor gene silenced by methylation in human colon aberrant crypt foci and cancers. PNAS 100 8412-8417. (doi:10.1073/pnas.1430846100)

Litvinov SV, Velders MP, Bakker HA, Fleuren GJ \& Warnaar SO 1994 Ep-CAM: a human epithelial antigen is a homophilic cell-cell adhesion molecule. Journal of Cell Biology 125 437-446. (doi:10. $1083 /$ jcb.125.2.437)

Maenhaut C, Detours V, Dom G, Handkiewicz-Junak D, OczkoWojciechowska M \& Jarzab B 2011 Gene expression profiles for radiation-induced thyroid cancer. Clinical Oncology 23 282-288. (doi:10.1016/j.clon.2011.01.509)

Malaguarnera R, Mandarino A, Mazzon E, Vella V, Gangemi P, Vancheri C, Vigneri P, Aloisi A, Vigneri R \& Frasca F 2005 The p53-homologue p63 may promote thyroid cancer progression. Endocrine-Related Cancer 12 953-971. (doi:10.1677/erc.1. 00968)

Matsumoto H, Sakamoto A, Fujiwara M, Yano Y, Shishido-Hara Y, Fujioka Y \& Kamma H 2008 Decreased expression of the thyroidstimulating hormone receptor in poorly-differentiated carcinoma of the thyroid. Oncology Reports 19 1405-1411.

Melamed D, Tiefenbrun N, Yarden A \& Kimchi A 1993 Interferons and interleukin-6 suppress the DNA-binding activity of E2F in growth-sensitive hematopoietic cells. Molecular and Cellular Biology 13 5255-5265.

Mesa C Jr, Mirza M, Mitsutake N, Sartor M, Medvedovic M, Tomlinson C, Knauf JA, Weber GF \& Fagin JA 2006 Conditional activation of RET/PTC3 and BRAFV600E in thyroid cells is associated with gene expression profiles that predict a preferential role of BRAF in extracellular matrix remodeling. Cancer Research 66 6521-6529. (doi:10.1158/0008-5472.CAN-06-0739)

Mishra A, Agrawal V, Krishnani N \& Mishra SK 2009 Prevalence of RET/PTC expression in papillary thyroid carcinoma and its correlation with prognostic factors in a north Indian population. Journal of Postgraduate Medicine 55 171-175. (doi:10.4103/0022-3859. 57390)

Miyagi E, Braga-Basaria M, Hardy E, Vasko V, Burman KD, Jhiang S, Saji M \& Ringel MD 2004 Chronic expression of RET/PTC 3 enhances basal and insulin-stimulated PI3 kinase/AKT signaling and increases IRS-2 expression in FRTL-5 thyroid cells. Molecular Carcinogenesis 41 98-107. (doi:10.1002/mc.20042)

Montero-Conde C, Martin-Campos JM, Lerma E, Gimenez G, Martinez-Guitarte JL, Combalia N, Montaner D, Matias-Guiu X, Dopazo J, de Leiva A et al. 2008 Molecular profiling related to poor prognosis in thyroid carcinoma. Combining gene expression data and biological information. Oncogene 27 1554-1561. (doi:10.1038/ sj.onc.1210792)

Nakamura N, Carney JA, Jin L, Kajita S, Pallares J, Zhang H, Qian X, Sebo TJ, Erickson LA \& Lloyd RV 2005 RASSF1A and NORE1A methylation and BRAFV600E mutations in thyroid tumors. Laboratory Investigation 85 1065-1075. (doi:10.1038/labinvest. 3700306)

Nappi TC, Salerno P, Zitzelsberger H, Carlomagno F, Salvatore G \& Santoro M 2009 Identification of Polo-like kinase 1 as a potential therapeutic target in anaplastic thyroid carcinoma. Cancer Research 69 1916-1923. (doi:10.1158/0008-5472.CAN-08-1693)

Nikiforova MN, Kimura ET, Gandhi M, Biddinger PW, Knauf JA, Basolo F, Zhu Z, Giannini R, Salvatore G, Fusco A et al. 2003 $a$ BRAF mutations in thyroid tumors are restricted to papillary carcinomas and anaplastic or poorly differentiated carcinomas arising from papillary carcinomas. Journal of Clinical Endocrinology and Metabolism 88 5399-5404. (doi:10.1210/jc.2003-030838) 
Nikiforova MN, Lynch RA, Biddinger PW, Alexander EK, Dorn GW, Tallini G, Kroll TG \& Nikiforov YE $2003 b$ RAS point mutations and PAX8-PPAR gamma rearrangement in thyroid tumors: evidence for distinct molecular pathways in thyroid follicular carcinoma. Journal of Clinical Endocrinology and Metabolism 88 2318-2326. (doi:10.1210/jc.2002-021907)

Nucera C, Porrello A, Antonello ZA, Mekel M, Nehs MA, Giordano TJ, Gerald D, Benjamin LE, Priolo C, Puxeddu E et al. 2010 B-Raf (V600E) and thrombospondin-1 promote thyroid cancer progression. PNAS 107 10649-10654. (doi:10.1073/pnas.1004934107)

Oler G, Camacho CP, Hojaij FC, Michaluart P Jr, Riggins GJ \& Cerutti JM 2008 Gene expression profiling of papillary thyroid carcinoma identifies transcripts correlated with BRAF mutational status and lymph node metastasis. Clinical Cancer Research 14 4735-4742. (doi:10.1158/1078-0432.CCR-07-4372)

Onda M, Emi M, Yoshida A, Miyamoto S, Akaishi J, Asaka S, Mizutani K, Shimizu K, Nagahama M, Ito K et al. 2004 Comprehensive gene expression profiling of anaplastic thyroid cancers with cDNA microarray of 25344 genes. Endocrine-Related Cancer 11 843-854. (doi:10.1677/erc.1.00818)

Pita JM, Banito A, Cavaco BM \& Leite V 2009 Gene expression profiling associated with the progression to poorly differentiated thyroid carcinomas. British Journal of Cancer 101 1782-1791. (doi:10. 1038/sj.bjc.6605340)

Placzkowski KA, Reddi HV, Grebe SK, Eberhardt NL \& McIver B 2008 The Role of the PAX8/PPARgamma fusion oncogene in thyroid cancer. PPAR Research 2008 672829. (doi:10.1155/2008/672829)

Polanski A, Polanska J, Jarzab M, Wiench M \& Jarzab B 2007 Application of Bayesian networks for inferring cause-effect relations from gene expression profiles of cancer versus normal cells. Mathematical Biosciences 209 528-546. (doi:10.1016/j.mbs.2007.03. 006)

Porra V, Ferraro-Peyret C, Durand C, Selmi-Ruby S, Giroud H, BergerDutrieux N, Decaussin M, Peix JL, Bournaud C, Orgiazzi J et al. 2005 Silencing of the tumor suppressor gene SLC5A8 is associated with BRAF mutations in classical papillary thyroid carcinomas. Journal of Clinical Endocrinology and Metabolism 90 3028-3035. (doi:10.1210/jc. 2004-1394)

Powell DJ Jr, Russell J, Nibu K, Li G, Rhee E, Liao M, Goldstein M, Keane WM, Santoro M, Fusco A et al. 1998 The RET/PTC3 oncogene: metastatic solid-type papillary carcinomas in murine thyroids. Cancer Research $\mathbf{5 8}$ 5523-5528.

Prasad ML, Pellegata NS, Kloos RT, Barbacioru C, Huang Y \& de la Chapelle A 2004 CITED1 protein expression suggests papillary thyroid carcinoma in high throughput tissue microarray-based study. Thyroid 14 169-175. (doi:10.1089/105072504773297830)

Pratilas CA, Hanrahan AJ, Halilovic E, Persaud Y, Soh J, Chitale D, Shigematsu H, Yamamoto H, Sawai A, Janakiraman M et al. 2008 Genetic predictors of MEK dependence in non-small cell lung cancer. Cancer Research 68 9375-9383. (doi:10.1158/0008-5472. CAN-08-2223)

Puxeddu E \& Moretti S 2007 Clinical prognosis in BRAF-mutated PTC. Arquivos Brasileiros de Endocrinologia e Metabologia 51 736-747. (doi:10.1590/S0004-27302007000500011)

Rabes HM, Demidchik EP, Sidorow JD, Lengfelder E, Beimfohr C, Hoelzel D \& Klugbauer S 2000 Pattern of radiation-induced RET and NTRK1 rearrangements in 191 post-chernobyl papillary thyroid carcinomas: biological, phenotypic, and clinical implications. Clinical Cancer Research 6 1093-1103.

Rhodes DR, Yu J, Shanker K, Deshpande N, Varambally R, Ghosh D, Barrette T, Pandey A \& Chinnaiyan AM 2004 Large-scale metaanalysis of cancer microarray data identifies common transcriptional profiles of neoplastic transformation and progression. PNAS 101 9309-9314. (doi:10.1073/pnas.0401994101)

Riesco-Eizaguirre G \& Santisteban P 2007 New insights in thyroid follicular cell biology and its impact in thyroid cancer therapy. Endocrine-Related Cancer 14 957-977. (doi:10.1677/ERC-07-0085)
Riesco-Eizaguirre G, Rodriguez I, De la Vieja V, Costamagna E, Carrasco N, Nistal M \& Santisteban P 2009 The BRAFV600E oncogene induces transforming growth factor beta secretion leading to sodium iodide symporter repression and increased malignancy in thyroid cancer. Cancer Research 69 8317-8325. (doi:10.1158/0008-5472.CAN-09-1248)

Rodrigues R, Roque L, Espadinha C, Pinto A, Domingues R, Dinis J, Catarino A, Pereira T \& Leite V $2007 a$ Comparative genomic hybridization, BRAF, RAS, RET, and oligo-array analysis in aneuploid papillary thyroid carcinomas. Oncology Reports $\mathbf{1 8}$ 917-926.

Rodrigues RF, Roque L, Krug T \& Leite V $2007 b$ Poorly differentiated and anaplastic thyroid carcinomas: chromosomal and oligo-array profile of five new cell lines. British Journal of Cancer 96 1237-1245. (doi:10.1038/sj.bjc.6603578)

Romei C, Ciampi R, Faviana P, Agate L, Molinaro E, Bottici V, Basolo F, Miccoli P, Pacini F, Pinchera A et al. 2008 BRAFV600E mutation, but not RET/PTC rearrangements, is correlated with a lower expression of both thyroperoxidase and sodium iodide symporter genes in papillary thyroid cancer. Endocrine-Related Cancer 15 511-520. (doi:10.1677/ERC-07-0130)

Saltman B, Singh B, Hedvat CV, Wreesmann VB \& Ghossein R 2006 Patterns of expression of cell cycle/apoptosis genes along the spectrum of thyroid carcinoma progression. Surgery 140 899-905. (doi:10.1016/j.surg.2006.07.027)

Salvatore G, Nappi TC, Salerno P, Jiang Y, Garbi C, Ugolini C, Miccoli P, Basolo F, Castellone MD, Cirafici AM et al. 2007 A cell proliferation and chromosomal instability signature in anaplastic thyroid carcinoma. Cancer Research 67 10148-10158. (doi:10.1158/00085472.CAN-07-1887)

Santoro M, Dathan NA, Berlingieri MT, Bongarzone I, Paulin C, Grieco M, Pierotti MA, Vecchio G \& Fusco A 1994 Molecular characterization of RET/PTC3; a novel rearranged version of the RET proto-oncogene in a human thyroid papillary carcinoma. Oncogene 9 509-516.

Santoro M, Papotti M, Chiappetta G, Garcia-Rostan G, Volante M, Johnson C, Camp RL, Pentimalli F, Monaco C, Herrero A et al. 2002 RET activation and clinicopathologic features in poorly differentiated thyroid tumors. Journal of Clinical Endocrinology and Metabolism 87 370-379. (doi:10.1210/jc.87.1.370)

Schiffman JD, Hodgson JG, VandenBerg SR, Flaherty P, Polley MY, Yu M, Fisher PG, Rowitch DH, Ford JM, Berger MS et al. 2010 Oncogenic BRAF mutation with CDKN2A inactivation is characteristic of a subset of pediatric malignant astrocytomas. Cancer Research 70 512-519. (doi:10.1158/0008-5472.CAN09-1851)

Schwartzenberg-Bar-Yoseph F, Armoni M \& Karnieli E 2004 The tumor suppressor p53 down-regulates glucose transporters GLUT1 and GLUT4 gene expression. Cancer Research 64 2627-2633. (doi:10. 1158/0008-5472.CAN-03-0846)

Scrideli CA, Carlotti CG Jr, Okamoto OK, Andrade VS, Cortez MA, Motta FJ, Lucio-Eterovic AK, Neder L, Rosemberg S, Oba-Shinjo SM et al. 2008 Gene expression profile analysis of primary glioblastomas and non-neoplastic brain tissue: identification of potential target genes by oligonucleotide microarray and real-time quantitative PCR. Journal of Neuro-Oncology 88 281-291. (doi:10.1007/s11060008-9579-4)

Sheu SY, Grabellus F, Schwertheim S, Handke S, Worm K \& Schmid KW 2009 Lack of correlation between BRAF V600E mutational status and the expression profile of a distinct set of miRNAs in papillary thyroid carcinoma. Hormone and Metabolic Research 41 482-487. (doi:10.1055/s-0029-1215558)

Soares P \& Sobrinho-Simoes M 2011 Cancer: small papillary thyroid cancers - is BRAF of prognostic value? Nature Reviews. Endocrinology 7 9-10. (doi:10.1038/nrendo.2010.213)

Spizzo G, Went P, Dirnhofer S, Obrist P, Simon R, Spichtin H, Maurer R, Metzger U, von Castelberg B, Bart R et al. 2004 High Ep-CAM 
expression is associated with poor prognosis in node-positive breast cancer. Breast Cancer Research and Treatment 86 207-213. (doi:10. 1023/B:BREA.0000036787.59816.01)

Tabach Y, Milyavsky M, Shats I, Brosh R, Zuk O, Yitzhaky A, Mantovani R, Domany E, Rotter V \& Pilpel Y 2005 The promoters of human cell cycle genes integrate signals from two tumor suppressive pathways during cellular transformation. Molecular Systems Biology 12005. (doi:10.1038/msb4100030)

Takano T, Matsuzuka F, Miyauchi A, Yokozawa T, Liu G, Morita S, Kuma K \& Amino N 1998 Restricted expression of oncofetal fibronectin mRNA in thyroid papillary and anaplastic carcinoma: an in situ hybridization study. British Journal of Cancer 78 221-224. (doi:10.1038/bjc.1998.468)

Terrile M, Appolloni I, Calzolari F, Perris R, Tutucci E \& Malatesta P 2010 PDGF-B-driven gliomagenesis can occur in the absence of the proteoglycan NG2. BMC Cancer 10 550. (doi:10.1186/14712407-10-550)

Thomas NE 2006 BRAF somatic mutations in malignant melanoma and melanocytic naevi. Melanoma Research 16 97-103. (doi:10.1097/ 01.cmr.0000215035.38436.87)

Vasko V, Ferrand M, Di Cristofaro J, Carayon P, Henry JF \& de Micco C 2003 Specific pattern of RAS oncogene mutations in follicular thyroid tumors. Journal of Clinical Endocrinology and Metabolism $\mathbf{8 8}$ 2745-2752. (doi:10.1210/jc.2002-021186)

Vasko V, Espinosa AV, Scouten W, He H, Auer H, Liyanarachchi S, Larin A, Savchenko V, Francis GL, de la Chapelle A et al. 2007 Gene expression and functional evidence of epithelial-to-mesenchymal transition in papillary thyroid carcinoma invasion. PNAS $\mathbf{1 0 4}$ 2803-2808. (doi:10.1073/pnas.0610733104)

Visconti R, Federico A, Coppola V, Pentimalli F, Berlingieri MT, Pallante P, Kruhoffer M, Orntoft TF \& Fusco A 2007 Transcriptional profile of Ki-Ras-induced transformation of thyroid cells. Cancer Investigation 25 256-266. (doi:10.1080/07357900701206406)

Visone R, Pallante P, Vecchione A, Cirombella R, Ferracin M, Ferraro A, Volinia S, Coluzzi S, Leone V, Borbone E et al. 2007 Specific microRNAs are downregulated in human thyroid anaplastic carcinomas. Oncogene 26 7590-7595. (doi:10.1038/sj.onc.1210564)

Volante M, Rapa I, Gandhi M, Bussolati G, Giachino D, Papotti M \& Nikiforov YE 2009 RAS mutations are the predominant molecular alteration in poorly differentiated thyroid carcinomas and bear prognostic impact. Journal of Clinical Endocrinology and Metabolism 94 4735-4741. (doi:10.1210/jc.2009-1233)

Wang Y, Ji M, Wang W, Miao Z, Hou P, Chen X, Xu F, Zhu G, Sun X, Li $\mathrm{Y}$ et al. 2008 Association of the T1799A BRAF mutation with tumor extrathyroidal invasion, higher peripheral platelet counts, and overexpression of platelet-derived growth factor-B in papillary thyroid cancer. Endocrine-Related Cancer 15 183-190. (doi:10.1677/ERC-070182)

Watanabe R, Hayashi Y, Sassa M, Kikumori T, Imai T, Kiuchi T \& Murata Y 2009 Possible involvement of BRAFV600E in altered gene expression in papillary thyroid cancer. Endocrine Journal 56 407-414. (doi:10.1507/endocrj.K08E-329)

Weber F, Shen L, Aldred MA, Morrison CD, Frilling A, Saji M, Schuppert F, Broelsch CE, Ringel MD \& Eng C 2005 Genetic classification of benign and malignant thyroid follicular neoplasia based on a three-gene combination. Journal of Clinical Endocrinology and Metabolism 90 2512-2521. (doi:10.1210/jc.2004-2028)
Whitfield ML, George LK, Grant GD \& Perou CM 2006 Common markers of proliferation. Nature Reviews. Cancer 6 99-106. (doi:10. 1038/nrc1802)

Williams ED, Abrosimov A, Bogdanova T, Demidchik EP, Ito M, LiVolsi V, Lushnikov E, Rosai J, Sidorov Y, Tronko MD et al. 2004 Thyroid carcinoma after Chernobyl latent period, morphology and aggressiveness. British Journal of Cancer 90 2219-2224. (doi:10. 1038/sj.bjc.6601860)

Wreesmann VB, Ghossein RA, Patel SG, Harris CP, Schnaser EA, Shaha AR, Tuttle RM, Shah JP, Rao PH \& Singh B 2002 Genome-wide appraisal of thyroid cancer progression. American Journal of Pathology 161 1549-1556. (doi:10.1016/S0002-9440(10) 64433-1)

Xing M, Westra WH, Tufano RP, Cohen Y, Rosenbaum E, Rhoden KJ, Carson KA, Vasko V, Larin A, Tallini G et al. 2005 BRAF mutation predicts a poorer clinical prognosis for papillary thyroid cancer. Journal of Clinical Endocrinology and Metabolism 90 6373-6379. (doi:10.1210/jc.2005-0987)

Yahata T, de Caestecker MP, Lechleider RJ, Andriole S, Roberts AB, Isselbacher KJ \& Shioda T 2000 The MSG1 non-DNA-binding transactivator binds to the $\mathrm{p} 300 / \mathrm{CBP}$ coactivators, enhancing their functional link to the Smad transcription factors. Journal of Biological Chemistry 275 8825-8834. (doi:10.1074/jbc.275.12.8825)

Yang Q, Ye ZY, Zhang JX, Tao HQ, Li SG \& Zhao ZS 2010 Expression of matrix metalloproteinase-9 mRNA and vascular endothelial growth factor protein in gastric carcinoma and its relationship to its pathological features and prognosis. Anatomical Record 293 2012-2019. (doi:10.1002/ar.21071)

Yano Y, Uematsu N, Yashiro T, Hara H, Ueno E, Miwa M, Tsujimoto G, Aiyoshi Y \& Uchida K 2004 Gene expression profiling identifies platelet-derived growth factor as a diagnostic molecular marker for papillary thyroid carcinoma. Clinical Cancer Research 10 2035-2043. (doi:10.1158/1078-0432.CCR-0807-03)

Yoon H, He H, Nagy R, Davuluri R, Suster S, Schoenberg D, Pellegata N \& Chapelle AL 2007 Identification of a novel noncoding RNA gene, NAMA, that is downregulated in papillary thyroid carcinoma with BRAF mutation and associated with growth arrest. International Journal of Cancer 121 767-775. (doi:10. 1002/ijc.22701)

Yousem SA, Nikiforova M \& Nikiforov Y 2008 The histopathology of BRAF-V600E-mutated lung adenocarcinoma. American Journal of Surgical Pathology 32 1317-1321. (doi:10.1097/PAS.0b013e31816 $597 \mathrm{ca})$

Zhu Z, Gandhi M, Nikiforova MN, Fischer AH \& Nikiforov YE 2003 Molecular profile and clinical-pathologic features of the follicular variant of papillary thyroid carcinoma. An unusually high prevalence of ras mutations. American Journal of Clinical Pathology 120 71-77. (doi:10.1309/ND8D9LAJTRCTG6QD)

Received in final form 18 July 2011

Accepted 28 July 2011

Made available online as an Accepted Preprint 28 July 2011 